\title{
Effects of Topographical Modification on the Composition and Abundance of Macrofauna in Southern Lagos Lagoon (Ikoyi)
}

\author{
C. A. Brown' and E. A. Ajao
}

'Department of Zoology, Marine Biology and Fisheries, University of Lagos, Akoka, Lagos, Nigeria (Email:<ogunwenmo@hotmail.com>)

'Institute of Oceanography and Marine Research, Lagos Island, Lagos, Nigeria

\begin{abstract}
The seasonal variation of macrobenthos at lkoyi was investigated between February 1985 and January 1990. Mean values of surface water temperature, salinity, and percentage mud in sediment and total organic matter were 27.89 "C, $12.22 \% 020.36 \%$, and $5.41 \%$, respectively. There were no deviations from normal values in a tropical estuarine open lagoon system. Mollusca, Arthropoda, Annelida, Chordata, Nemertina and Chaetognatha were collected. The gastropod mollusc, Pachymelania aurita, ranked highest on all but two sampling dates, where Tympanotonus fuscatus and Aloidis trigona ranked first. Changes in salinity and sediment type were main factors contributing to reduction of species, dominance diversity and change in community structure, which were attributed to habitat modification caused by dredging and sand filling.
\end{abstract}

\section{Introduction}

Lagos lagoon is the largest brackish water body of the southern lagoon system in Nigeria. (Webb, 1958). Although various aspects of the physical properties (Hill \& Webb, 1958; Olaniyan, 1969), such as plankton(Olaniyan, 1969; Nwankwo, 1990), epiphytes (Nwankwo \& Akinsoji, 1992), finfish (Fagade, 1971, 1979; Fagade \& Olaniyan, 1972, 1973, 1974), shell fish (Yoloye, 1974; Yoloye \& Adegoke, 1977; Oyenekan, 1979; Oyenekan \& Bolufawi, 1986; Ajao \& Fagade, 1990a, 1990b, 1990c, 1990d, 1990e; Brown \& Oyenekan, 1998), and other fauna (Hill, 1967) have been studied with inputs on pollution (Ekundayo, 1977; Akpata \& Ekundayo, 1978; Akpata et al., 1993; Otitoloju, 2002, 2003), as well as mining (Awosika \& Dublin-Green, 1994), a census of the present status of the macrobenthic community is necessary due to increased pollution, population explosion and anthropogenic activities in and around the lagoon.

Longhurst (1958) observed bottom sediments and fauna in the West African continental shelf. Fauna classified by communities belonged to various taxa. Earlier, Smith (1871) described shells from West Africa, hitherto unidentified. Later, Webb (1958) studied the life cycle of Branchiostoma nigeriense in the Lagos lagoon. After this there was a dearth of information on benthos in the Lagos lagoon, until Sandison (1966) and Sandison \& Hill (1966) observed effects of salinity on macrobenthic fauna in and around the Lagos harbour and adjacent creeks. Yoloye \& Adegoke (1977) named a new species of Neritina from the Lagos lagoon. The next extensive survey on macrobenthic fauna was not carried out until the next decade when Oyenekan (1987) described the benthic macrofaunal communities of the 
Lagos lagoon. He described five communities by biotype and biocenosis. More recently, Ajao \& Fagade (1990a, $1990 \mathrm{~b}, 1990 \mathrm{c}$ ) also studied these communities and concluded that the major cause of reduction to extremely low diversities and densities was due to the discharge of various types of untreated wastes into the Lagos lagoon by identified industries. They also recognized a shift in the characteristic fauna in the western industrialized region and eastern unpolluted region. In addition untreated sewage and effluent is discharged into the lagoon (Nwakoro \& Odiete, 1997), sand is mined indiscriminately (Awosika \& Dublin-Green, 1994), and, in some areas, communities have been completely destroyed by dredging and sand filling activities.

It has, therefore, become imperative to assess the effect of habitat destabilization and modification (caused by dredging activities which evacuate the sediment bottom and sand filling over the mangrove swamp and macrobenthic community), on this localized area in the southern Lagos lagoon, with a view to assessing the problem, profer solutions and prevent further defaunation.

\section{Materials and methods}

Benthic samples were taken in the rainy season (June 1985 and 1986, and July 1987 , 1988 and 1989) and dry season (February 1985 and 1986, and January 1988 and 1990) at Ikoyi (Fig. 1), using a $0.1 \mathrm{~m}^{2}$ Van-Veen grab. No samples were collected from Ikoyi in May 1996 because sand filling and dredging of the surrounding offshore sites made the area too deep to be sampled. Six grab hauls were taken at each station. Benthic fauna were retrieved from five hauls after Crisp (1971), while the sixth grab haul was used for sediment analysis. Five grab hauls were washed through a 0.5 $\mathrm{mm}$ mesh sieve in the field. The retained material was preserved in $5 \%$ formalin and kept in labeled jars for further analysis in the laboratory. The sixth grab haul was placed in a labeled polyethylene bag for preservation in the deep freezer in the laboratory for sediment analysis.

Preliminary investigations showed that surface water temperature and bottom water temperature in the Lagos lagoon ranged between $25^{\circ} \mathrm{C}$ and $28^{\circ} \mathrm{C}$. Surface water temperatures were, therefore, taken to the nearest whole number, using a mercury-in-glass-thermometer at Ikoyi in the rainy and dry seasoris. Water samples were collected with a glass water sampler and stored in clear glass bottles for salinity determination using a temperature compensated hand refractometer (New S100 ), in the laboratory. Sediment samples were thawed and dried for $6-8 \mathrm{~h}$ at $\mathbf{6 0 - 8 0}$ ${ }^{\circ} \mathrm{C}$, to a constant weight. Grain size analysis was carried out as described by Buchanan \& Kain (1971). Total organic matter(TOM) was determined using the method described by Oyenekan (1981), and the percentage of combustible material in the sediment was estimated as:

\section{Loss of weight on ignition \\ Initial weight before ignition $100 \%$}

The organisms preserved in the field were washed, sorted into taxonomic groups and counted. Faunal density was expressed as species per square metre $\left(\mathrm{m}^{-2}\right)$. Species were ranked and the contributions of the first five numerically dominant species were recorded. 


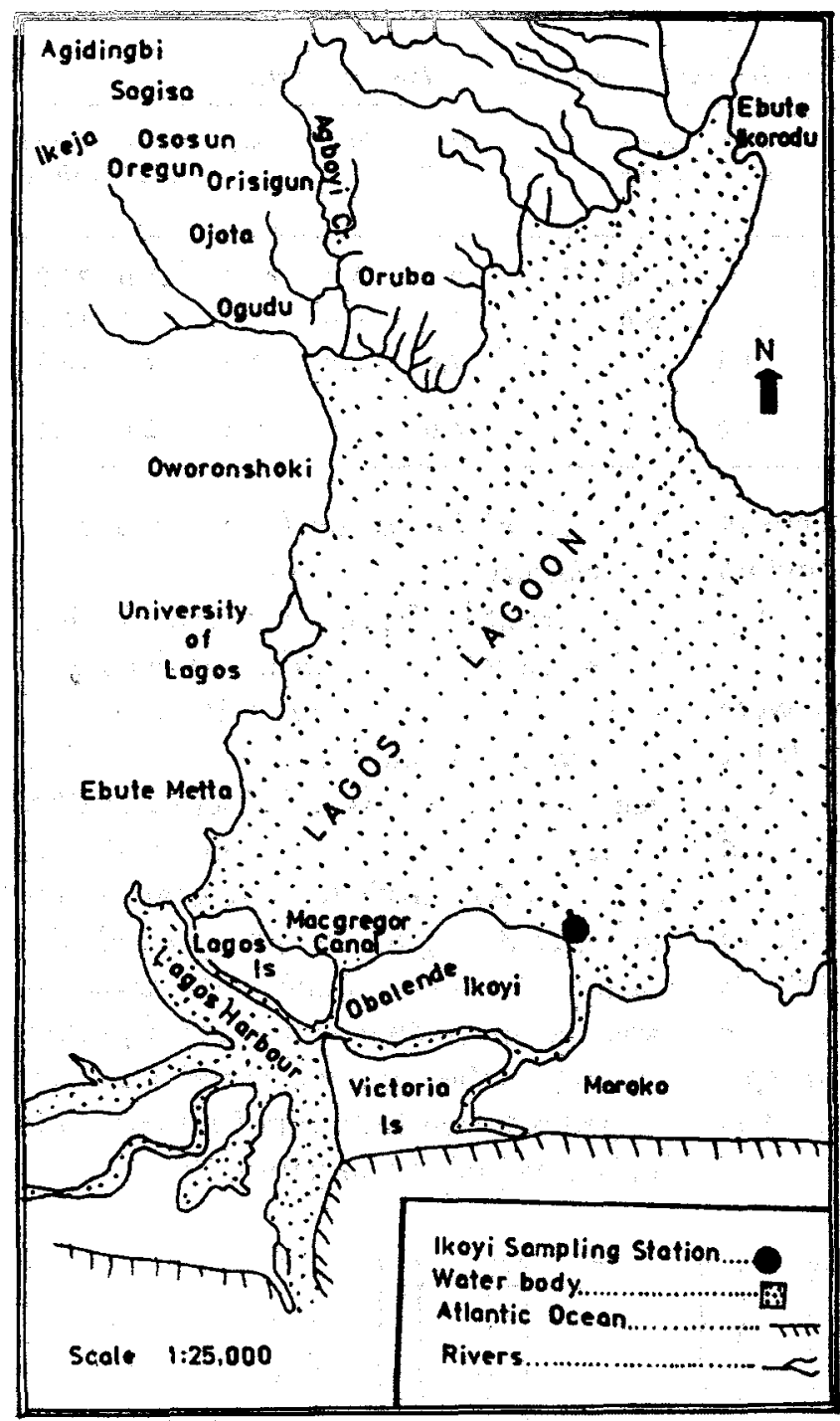

Fig. 1. Map of Lagos lagoon showing Ikoyi sampling station

$\mathrm{N}=$ number of individuals, $\log _{\mathrm{e}}$ =natural logarithm.

Shannon and Weaver Information Function

$$
\begin{aligned}
& H s=p_{i} \log _{e} p_{i} \\
& S=\text { total number of }
\end{aligned}
$$

species; $p_{i}=$ observed proportion of individuals that belong to the $\mathrm{i}^{\text {th }}$ species.

Equitability

$$
\begin{aligned}
J= & \mathrm{Hs} \\
& \log _{2} \mathrm{~S}
\end{aligned}
$$

$\mathrm{J}=$ equitability measure

Hs = Shannon and Weaver Information Function

$S$ = number of species in sample or community

\section{Results}

Physical and chemical properties

Surface water temperature was narrow $\left(26-30^{\circ} \mathrm{C}\right)$ with a mean of $27.89^{\circ} \mathrm{C}$, salinity values were between $0 \%$ (June and July), and 29\% (February) with a mean of $12.22 \%$. Total organic matter was low $(<20.0 \%)$ while percentage mud in sediment ranged between $1.3 \%$ in

Margalef's Index (Margalef, 1957), Shannon and Weaver Information Function (Shannon \& Weaver, 1963), and Equitability (Lloyd \& Ghellardi, 1964) were used to measure diversity in the environment.

Margalef's Index

$$
\begin{aligned}
d= & S-1 \\
& \log _{e} N
\end{aligned}
$$

$\mathrm{d}=$ diversity index, $\mathrm{S}=$ number of species,

February 1986 and $83.2 \%$ in February 1985 and had a mean of $5.41 \%$ (Table I).

\section{Major animal taxa}

The seasonal distribution of phyla at Ikoyi shows a community dominated by molluses (gastropods and bivalves), which contributed between $77.1 \%$ (January) and 100.0\% (February 1986) of total fauna collected at 
Variation in some physico-chemical parameters during 1985 to 1990

Sampling dates

Parameters

Surface water temp. ("C)

Salinity (\%o)

Mud in sediment (\%)

Total organic matter in

sediment $(\%)$

$\begin{array}{lllllllll}\text { Feb } & \text { June } & \text { Feb } & \text { June } & \text { July } & \text { Jan } & \text { July } & \text { July } & \text { Jan Mean } \\ 1985 & 1985 & 1986 & 1986 & 1987 & 1988 & 1988 & 1989 & 1990 \text { valuea }\end{array}$

$\begin{array}{rrrrrrrrrr}27.0 & 27.0 & 30.0 & 27.0 & 26.0 & 30.0 & 28.0 & 28.0 & 28.0 & 27.89 \\ 29.0 & 0.0 & 27.0 & 5.0 & 3.0 & 21.0 & 0.0 & 1.0 & 24.0 & 12.22 \\ 83.2 & 39.4 & 1.3 & 3.7 & 22.7 & 19.0 & 6.9 & 4.3 & 2.7 & 20.36 \\ 17.8 & 19.1 & 1.0 & 0.5 & 2.0 & 4.0 & 1.0 & 1.3 & 2.0 & 5.41\end{array}$

Ikoyi. (Fig. 2). There was a higher density of gastropods than bivalves. The phylum Annelida contributed between $0.5 \%$ (July 1989 ) and $18.7 \%$ (February 1985) of fauna collected. Crustacean arthropods were present and contributed between $0.1 \%$ (February 1986) and 23.8\%(February 1985). Phylum Nemertina contributed to $4.8 \%$ of the sample collected in February 1985. Phylum Chordata contributed $0.1 \%$ of sample collected in February 1986 and $0.3 \%$ of sample collected in January 1990. The phylum Chaetognatha (Sagitta sp.) contributed $0.1 \%$ of sample collected in June 1986 (Fig. 2).
Species richness and abundance of individuals

The number of species per $\mathrm{m}^{2}$ was highest in February $1985\left(26 / \mathrm{m}^{2}\right)$. The density of species collected in January 1990 and July 1988 were 11 and 12 , respectively. The density of individuals varied between $10 / \mathrm{m}^{2}$ (June 1985) and 60, 104/ $\mathrm{m}^{2}$ (February 1986) (Table 2). A total of 37 different fauna were collected during the sampling period. The gastropod mollusc, Pachymelania aurita, was the most abundant species present throughout the sampling period. Densities ranged between $120 / \mathrm{m}^{2}$ in February 1985 and $60,056 / \mathrm{m}^{2}$ in February 1986.

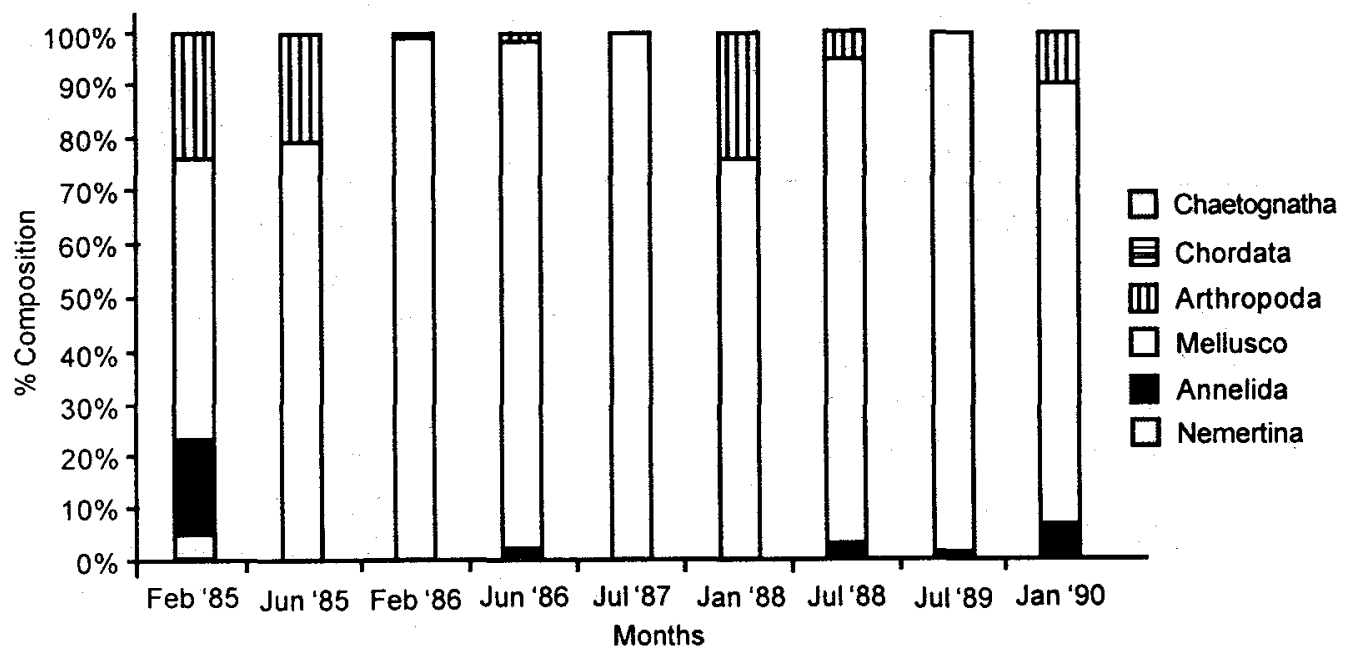

Fig. 2. Seasonal distribution of phyla at Ikoyi 
TABLE 2

Density of macrofauna per $m^{2}$ at lkoyi for wet and dry seasons between February 1985 and January 1990

\begin{tabular}{|c|c|c|c|c|c|c|c|c|c|}
\hline & $\begin{array}{l}F e b \\
1985\end{array}$ & $\begin{array}{l}\text { June } \\
1985\end{array}$ & $\begin{array}{l}F e b \\
1986\end{array}$ & $\begin{array}{l}\text { June } \\
1986\end{array}$ & $\begin{array}{l}\text { July } \\
1987\end{array}$ & $\begin{array}{l}\text { Jan } \\
1988\end{array}$ & $\begin{array}{l}\text { July } \\
1988\end{array}$ & $\begin{array}{l}\text { July } \\
1989\end{array}$ & $\begin{array}{l}\text { Jan } \\
1990\end{array}$ \\
\hline \multicolumn{10}{|l|}{ NEMERTINA } \\
\hline Nemertina & 28 & & & & & & & & \\
\hline \multicolumn{10}{|l|}{ ANNELIDA } \\
\hline Capitella capitata & 30 & & & & & & & & \\
\hline Glycera convoluta & 2 & & & & & & 4 & & \\
\hline Diopatra neapolitana & 10 & & & & & & & & \\
\hline Lumbrinereis sp. & 12 & & & & & & & & \\
\hline Mercierella enigmatica & 4 & & & & & & & & \\
\hline Nephtys sp. & & & & & & & & & 4 \\
\hline Nereis pelagica & & & & 20 & & & & & \\
\hline Nereis sp. & 12 & & & & & & & & \\
\hline Nereis succinea & & & & & & & 16 & 2 & 46 \\
\hline Phoronis muelleri & 2 & & & & & & & & \\
\hline Prionospio sp. & 2 & & & & & & & & \\
\hline Polydora sp. & 20 & & & & & & & & \\
\hline Syllidae & 8 & & & & & & & & \\
\hline Tubifex sp. & 8 & & & & & & & & \\
\hline \multicolumn{10}{|l|}{ MOLLUSCA } \\
\hline Pachymelania aurita & 120 & & 60056 & 1350 & 1535 & 1380 & 564 & 398 & 406 \\
\hline Tympanotonus fuscastus & 168 & & & & & & & & \\
\hline Neritina glabrata & & & 2 & 68 & & 5 & 72 & 16 & 130 \\
\hline Aloidis trigona & 4 & 4 & 4 & & & 10 & 6 & & \\
\hline Mytilus edulis & & & & & 5 & & & & \\
\hline Brachyodontes puniceus & 4 & & & & & & 4 & & \\
\hline Cultellus tenius & 6 & 4 & & & & & & & \\
\hline Diplodonta sp. & 2 & & & & & & & & \\
\hline Iphigenia truncata & 2 & & & & & & & & 4 \\
\hline Crassostrea gasar & 4 & & & 72 & & 5 & 20 & 2 & 16 \\
\hline \multicolumn{10}{|l|}{ ARTHROPODA } \\
\hline Balanus pallidus & 14 & & 32 & & & 400 & & & 10 \\
\hline Callinectes latimanus & 16 & & & & & & & & \\
\hline Sersarma huzardi & & & & & & & 2 & & \\
\hline Clibinarius africanus & 32 & & & 4 & & 15 & 8 & 14 & 44 \\
\hline Pachygrapsus transversus & & & & & & & 2 & & 2 \\
\hline Calappa rubroguttata & & & & & & & 4 & & \\
\hline Caprella linegris & 72 & & & & & & & & \\
\hline Corophium insidiosum & 4 & & & & & & & & \\
\hline Peneaus notialis & & & & & & & 12 & 12 & 6 \\
\hline $\begin{array}{l}\text { Unidentified amphipod } \\
\text { CHORDATA }\end{array}$ & 2 & 2 & & 10 & & & & & \\
\hline $\begin{array}{l}\text { Branchiostoma nigeriense } \\
\text { CHAETOGNATHA }\end{array}$ & 32 & & & & & & & & 2 \\
\hline Sagitta $s p$ & & & & 2 & & & & & \\
\hline Species & 26 & 3 & 4 & 7 & 2 & 6 & 12 & 6 & 11 \\
\hline Individuals & 588 & 10 & 60,104 & 1526 & 1540 & 1815 & 714 & 444 & 670 \\
\hline
\end{tabular}

West African Journal of Applied Ecology, vol. 5, 2004 
$P$. aurita ranked first in density among all species collected on all sampling dates except February 1985 when it ranked second to Tympanotonus fuscatus. Other highranking fauna were Neritina glabrata, Aloidis trigona, Crassostrea gazer, Nereis succinea, Caprella linegris, Capitella capitata, Nemertina, Cultellus tenius, unidentified amphipod, Balanus pallidus, Branchiostoma nigeriense, Nereis pelagica, Mytilus edulis, Clibinarius africanus and Peneaus notialis. (Table 3 ). During the dry season (February 1986), a lagoon visitor, $B$. nigeriense ranked second along side Balanus pallidus, while $M$. edulis also a marine species ranked second in July 1987.

\section{Faunal indices}

Margalef's Index values ranged between 0.14 in July 1987 and 3.92 in February 1985
(Table4). Shannon and Weaver Information Function values were highest in February 1985 (2.29) and lowest in February 1986 (0.1)(Table4). The equitability of individuals ranged from 0.01 (February 1986) to 0.66 (June 1985). (Table 4).

\section{Discussion}

The average surface water temperature at Ikoyi was $27.49^{\circ} \mathrm{C}$. This value was higher than that of earlier workers. Fagade (1969) obtained a surface water temperature of $24.8{ }^{\circ} \mathrm{C}$ in July 1967 off Ikoyi, while Oyenekan (1987) obtained a temperature of $26^{\circ} \mathrm{C}$ in October 1974. Salinity was lower in the wet season months (June and July) than the dry season months (January and February). Similar results were obtained from earlier workers (Fagade, 1969; Oyenekan, 1987; Brown, 1998).

The Pachymelania community was one

TABLE 3

Ranking of macrofauna at Ikoyi between February 1985 and January 1990

\begin{tabular}{|c|c|c|c|c|c|c|c|c|c|}
\hline & $\begin{array}{l}F e b \\
l 985\end{array}$ & $\begin{array}{l}\text { June } \\
\text { 1985 }\end{array}$ & $\begin{array}{c}F e b \\
1986\end{array}$ & $\begin{array}{l}\text { June } \\
1986\end{array}$ & $\begin{array}{l}\text { July } \\
1987\end{array}$ & $\begin{array}{c}\text { Jan } \\
\text { I988 }\end{array}$ & $\begin{array}{c}\text { July } \\
1988\end{array}$ & $\begin{array}{l}\text { July } \\
1989\end{array}$ & $\begin{array}{c}\text { Jan } \\
1990\end{array}$ \\
\hline Pachymelania aurita & 2 & & 1 & 1 & 1 & 1 & 1 & 1 & 1 \\
\hline Tympantonus fuscatus & 1 & & & & & & & & \\
\hline Neritina glabrata & & & 4 & 3 & & $5 *$ & 2 & 2 & 2 \\
\hline Aloidis trigona & & 1 & 3 & & & 4 & & & \\
\hline Crassostrea gazar & & & & 2 & & $5^{*}$ & 3 & $5 *$ & 5 \\
\hline Nereis succinea & & & & & & & 4 & $5^{*}$ & 3 \\
\hline Caprella linegris & 3 & & & & & & & & \\
\hline Capitella capitata & 4 & & & & & & & & \\
\hline Nermertina & 5 & & & & & & & & \\
\hline Cutellus tenuis & & 2 & & & & & & & \\
\hline Unidenified amphipod & & 3 & & 5 & & & & & \\
\hline Balamus pallidus & & & $2 *$ & & & 2 & & & \\
\hline Branchiostoma nigeriense & & & $2 *$ & & & & & & \\
\hline Nereis pelagica & & & & 4 & & & & & \\
\hline Mytilus edulis & & & & & 2 & & & & \\
\hline Clibinarius africanus & & & & & & 3 & & 3 & 4 \\
\hline Peneaus notialis & & & & & & & 5 & 4 & \\
\hline
\end{tabular}

* Same ranking 
TABLE 4

Faunal indices at lkoyi

$\begin{array}{cc}\begin{array}{c}\text { Margalef's } \\ \text { Index }\end{array} & \begin{array}{c}\text { Shannon \& Weaver } \\ \text { Information } \\ \text { Function }\end{array}\end{array}$

\begin{tabular}{llll}
\hline Feb. $\cdot 85$ & 3.92 & 2.29 & 0.49 \\
June $\cdot 85$ & 0.87 & 1.05 & 0.66 \\
Feb. $\cdot 86$ & 0.27 & 0.01 & 0.01 \\
June $\cdot 86$ & 0.83 & 0.38 & 0.13 \\
July $\cdot 87$ & 0.14 & 0.02 & 0.02 \\
Jan 88 & 0.67 & 0.64 & 0.25 \\
July 88 & 1.67 & 0.99 & 0.27 \\
July 89 & 0.82 & 0.50 & 0.19 \\
Jan 90 & 1.54 & 1.23 & 0.35 \\
\hline
\end{tabular}

about by sand filling the Mangrove Park at Ikoyi Island. The marine visitor (Branchiostoma nigeriense) reported at Ikoyi (Webb, 1958; Brown \& Oyenekan, 1998) was also collected at Ikoyi during the dry season months. Balanus pallidus (a typical mangrove species and fouling organism) also showed abundance during dry season samplings.

One Nemertina, 11 Annelida, three Mollusca and three Arthropoda species collected at Ikoyi in February 1985 were absent of the five communities described by Oyenekan (1987) in the Lagos lagoon; others were Mangrove, Estuarine, Venus and Estuarine rock communities. The Pachymelania community inhabited the main part of the Lagos lagoon and consisted of Pachymelania aurita, Aloidis trigona, Iphigenia truncata, Neritina glabrata, Branchiostoma nigeriensis, Glycera convoluta, Nereis succinea, Lumbrinereis sp., Diopatra neapolitanea and crustaceans, Clibinarius africana and Heteropanoe caparti. Tympanotonus fuscatus, Tagellus angulatus and Cultellus tenuis were also present. Presently in the modified Pachymelania community that had reduced in density and diversity from that recorded by Oyenekan(1987), Mollusca, Annelida and Arthropoda co-existed alongside Nemertina and Chaetognatha. The latter two were previously absent from this ecosystem. In addition, crabs (Sersarma huzardi, Pachygrapsus transversus and ('alappa rubroguttata) were also collected. Their presence in the open lagoon is unusual and suggests a possible change in habitat. which could have been brought at later sampling dates. The change in community structure from Pachymelania community to mangrove community indicates a change in either density or diversity of macrobenthic fauna at Ikoyi. These changes are not independent of physico-chemical factors. Oyenekan (1987) observed muddy fine sand at Ikoyi; this later changed to sandy mud (Ajao, 1990d). This could have been attributed to the high diversity observed in February 1985, which dwindled in later sampling dates when the substrate became sandier. Similar reductions in habitat diversity from changes in substrate, current flow and depths (Gordan \& Carr, 1978) have also been implicated for shifts and reductions in the number of invertebrate species (Morris et al., 1968).

In addition to substrate type, salinity also determines diversity and density of fauna (Brown \& Oyenekan, 1998). The salinity at Ikoyi in February 1985 (29.0\%) was the highest collected from all sampling dates. Subsequently, lower salinities $(0-27 \%)$ and species diversity $\left(2-12 \mathrm{species} / \mathrm{m}^{2}\right)$ were recorded.

The dredging and sand filling activities at 
Ikoyi have pollution implications as they alter bottom conditions over sizeable areas (Ajao \& Fagade, 1990e) and destroy mollusc settlement areas (Cole, 1977). These have brought about variations in some physicochemical parameters and a significant reduction in species, and dominace diversity as well as change in community structure.

\section{Conclusion}

The present metamorphosis in community structure provides baseline information on physical, chemical and biological data in southern Lagos lagoon at Ikoyi. This could provide scientific basis for monitoring future ecological changes in the lagoon.

\section{Acknowledgement}

The author wishes to acknowledge the assistance rendered by $\mathrm{Mr}$ Okunomo and Mr Emubaiye in sample collection during the field rips, Dr J. A. Ajao for academic assistance, and $\mathrm{Mr} \mathrm{K}$. Ogunwenmo for reading the manuscript.

\section{References}

Ajao E. A. and Fagade S. O. (1990a). Production and population dynamics of Pachymelania aurita Müller. Arch. Hydrobiol. 12(1): 97 109.

Ajao E. A. and Fagade S. O. (1990b). The ecology of Capitella capitata in Lagos lagoon. Arch. Hydrobiol. 120(2): 229-239.

Ajao E. A. and Fagade S. O. (1990c). The ecology of Neritina glabrata in Lagos lagoon, Nigeria. Arch. Hydrobiol.119(3):339-350.

Ajao E. A. and Fagade S. O. (1990d). The distribution and abundance of Pachymelania aurita in Lagos lagoon, Nigeria. Arch. Hydrobiol. 119(4): 475-488.

Ajao E. A. and FagadeS. O.(1990e). A study of the sediments and communities in Lagos lagoon, Nigeria. J. Oil chem. Poll. 7:85-117. Akpata T. V. I., Oyenekan J. A. and Nwankwo
D. I. (1993). Impacts of organic pollution on the bacterial, planktonic and benthic populations of Lagos lagoon, Nigeria. Int. $J$. Ecol. envir. Sci. 19: 73 - 82.

Akpata T. V. I. and Ekundayo J. A. (1978). Faecal pollution of the Lagos lagoon. Niger. J. Sci. 12(1 \& 2): $39-53$.

Awosika L. F. and Dublin-Green C. O.(1994). Sand mining in the Lagos and Lekki lagoons and strategies for effective management. $J$. Min. Geol.30(11): 137-139.

Brown C. A. (1998). Distribution and population dynamics of an estuarine population of Aloidis trigona Hinds. (Bivalvia). Acta Hydrobiol. 40: 227-237.

Brown C. A. and Oyenekan J. A. (1998). Temporal variability in the structure of benthic macrofauna communities of the Lagos lagoon and harbour, Nigeria. Pol. Arch. Hydrobiol. 45(1):45-54.

Buchanan J. B. and Kain J. B. (1971). Measurement of physical and chemical environment. In Methods for the study of marine benthos (N. A. Holmes and A.D. McIntyre, ed.), pp. 30-58. Blackwell Scientific Publication.

Cole H. A. (1977). Sand and gravel extraction. Marine Pollution Bull. 8. 193 pp.

Crisp D.J. (1971). Energy flow measurements. In Methods for the study of marine benthos. (N.A. Holme and A.D. Mcintyre, ed.), pp. 197 -279. Blackwell Scientific Publications.

Ekundayo J. A. (1977). Environmental consequences of pollution of the Lagos lagoon. Bull. Sci. Ass. Niger. 3(2):290-299.

Fagade S. O. (1969). Studies on biology of some fishes of Lagos lagoon. (PhD Thesis.) University of Lagos, Nigeria. $358 \mathrm{pp}$.

Fagade S. O. (1971). The food and feeding habits of Tilapia species in Lagos lagoon. $J$. Fish. Biol.3: 151-156.

Fagade S. O. (1979). Observations on the biology of two species of Tilapia from the Lagos lagoon, Nigeria. Bull. D'IFAN41 (1): 629-654.

Fagade S. O. and Olaniyan C. I. O. (1972). The 
biology of the West African Shad, Ethmalosa ufimbriata (Bowdich) in the Lagos lagoon, Nigeria. J. Fish. Biol. 4: 519-534.

Fagade S. O. and Olaniyan C. I. O. (1973). The food and feeding interrelationship of the fishes in the Lagos lagoon. J. Fish. Biol. 5: $205-225$.

Fagade S. O. and Olaniyan C. I. O. (1974) Seasonal distribution of the fish fauna of the Lagos lagoon. Bull. d'IFAN36(1):244-252.

Gordan O. T. and Carr J. R. (1978). Habitat structure and stream fish communities. Ecology 59: 507-515.

Hill M. B. (1967). The life cycles and salinity tolerance of the serpulids Mercierella enigmatica (Fauvel) and Hydroides unciata (Philipi) at Lagos, Nigeria.J. Anim. Ecol. 36: 306-321.

Hill M. N. and Webb J. E. (1985). The ecology of Lagos lagoon II. The topography and physical features of Lagos harbour and Lagos lagoon. Phil. Trans. R. Soc. 241:307-419.

Lloyd M. and Ghellardi R. J. (1964) A table for calculating the equitability components for species diversity.J. Anim. Ecol. 33:217-225.

Longhurst A. R. (1958). An ecological survey of the west African Marine Benthos. Fishery Publs Lond. 11: 1-102.

Margalef R.(1957). La teoriade la informacion enecologia. Mems. R. Acad. 32:273-449.

Morris L. A., Longermeir R. N., Russel T. R. and Witt A. Jr. (1968). Effects of the mainstream impoundments and channelisation upon the limnology of the Missouri River, Nebraska. Trans. Am. Fish. Soc. 97(4): 380-388.

Nwankwo D. I. (1990). Distribution and seasonal variation of dinoflagellates in Lagos lagoon. Niger. J. Bot. 3(53): 197-208.

Nwankwo D. I. and Akinsoji A. (1992). Epiphyte community on water hyacinth Eichhornia crassipes (Mart) Solms in coastal waters of southwestern Nigeria. Arch. Hydrobiol. 124 (4): 501-511.

Nwaokoro R. C. and Odiete W. O. (1997). Baseline survey of industries, industrial wastewaters and waterbodies receiving industrial wastewaters in Lagos State. World Bank funded project for Ministry of Environmental \& Physical Planning. Ikeja. $77 \mathrm{pp}$.

Olaniyan C. I.O. (1969). The seasonal variation in the hydrology and total plankton of the lagoons of southwest Nigeria. Niger. J. Sci. 3(2): 101-119.

Otitoloju A. A. (2002). Evaluation of joint action toxicity of binary mixtures of heavy metals against the mangrove periwinkle Tympanotonus fuscatus var. radula (L.). Ecotoxicol. envir. Safety. 53: 404-415.

Otitoloju A. A. (2003). Relevance of joint action toxicity evaluations in setting realistic environmental safe limits of heavy metals. $J$. envir. Mgmt 67: 121-128.

Oyenekan J. A. (1979). The ecology of the genus Pachymelania in Lagos lagoon. Arch. Hydrobiol.86(4):515-522.

Oyenekan J. A. (1981). Community structure and production of benthic macrofauna of Southampton water. (PhD Thesis.). University of Southampton. $351 \mathrm{pp}$.

Oyenekan J. A. (1987). Benthic macrofaunal c mmunities of Lagos lagoon, Nigeria. Niger. J. Sci. 21:45-51.

Oyenekan J. A. and Bolufawi J. E. (1986). The ecology of Iphigenia truncata in Lagos lagoon. Arch. Hydrobiol. 106(4): 559-566.

Sandison E. E. (1966). The effect of salinity fluctuations on the life of Balanus pallidus Strusburi (Darwin) in Lagos harbour, Nigeria. J. Anim. Ecol. 35: 363 - 378.

Sandison E. E. and Hill M. B. (1966). The distribution of Balanus pallidus Strutburi Darwin, Gryphea gazer Adanson, Dautzenbury, Mercierellaenigmatica Fauvel and Hydroides uncinata (Phillippi) in relation to salinity in Lagos harbour and adjacent creeks. J. Anim. Ecol.35: 235 - 258 .

Shannon C. E. and Weaver W. (1963). The Mathematical Theory of Communication. University of Illinois Press. Urbana. $125 \mathrm{pp}$. Smith E. A. (1871). A list of species of shells 
from West A frica, with descriptions of those hitherto described. Bull. Brit. Mus. Nat. Hist. Zool. 727-739.

Webb J. E. (1958). The ecology of Lagos lagoon. I. The lagoon of the Guinea Coast. Phil. Trans. R. Soc. Lond. 683(241): 307318.

Williams N. V. (1962). The seasonal distribution of the teleost fish in Lagos harbour, creek and lagoon in relation to salt
tolerance(MSc Thesis.). University College, North Wales. Bangar. pp. 80-90.

Yoloye V. L. (1974). The sexual phase of the West African cockle Anadara senilis. Proc. malac. Soc. Lond. 41:25-28.

Yoloye V. and Adegoke S. (1977). A new species of Neritina. (Archaeogastropoda, Neritidae) from the Lagos lagoon. Malacologia 16(1): 303-309. 